\title{
OPTIMISATION OF ENZYMATIC DIRECTED INTERESTERIFICATION OF PALM OIL FOR HIGH YIELD OF TRIUNSATURATED TRIACYLGLYCEROL USING RESPONSE SURFACE METHODOLOGY
}

\author{
NOOR LIDA HABI MAT DIAN*; MISKANDAR MAT SAHRI*; TAN CHIN PING**; \\ LEE YEE YING ${ }^{\ddagger}$ and LAI OI MING $\neq$
}

\begin{abstract}
Unsaturated fatty acids (USAFA), especially monounsaturated fatty acids (MUFA), has been shown to provide substantial health benefits. This study attempted to increase the triunsaturated $\left(U_{3}\right)$ triacylglycerols (TAG) content in palm oil (PO) via lipase-catalysed directed interesterification (EDIE), to enable the production of a liquid fraction that is high in USAFA, especially MUFA. A response surface methodology with three factors and five levels in a central composite design was employed for optimisation of the EDIE conditions for the $U_{3} T A G$ production. The effects of reaction temperature $\left(20^{\circ} \mathrm{C}-50^{\circ} \mathrm{C}\right)$, reaction time $(12-28 \mathrm{hr})$ and enzyme load $(2 \%-18 \%)$ on the $U_{3} T A G$ and by-products yields were investigated. Well-fitted quadratic and linear models were successfully established for both responses. All processing conditions affected significantly $(p<0.05) U_{3} T A G$ yield. By-products yield was affected by reaction time and temperature. Although increasing reaction temperature and enzyme load, and extending the reaction time resulted in a higher $U_{3} T A G$ yield, a higher amount of by-products were formed as well. The optimised processing conditions were a reaction temperature of $30^{\circ} \mathrm{C}$ and reaction time of $18 \mathrm{hr}$, when immobilised lipase enzyme load was set at 10\% (w/w), and resulted in yields of about $27 \%$ of $U_{3} T A G$ and $23 \%$ of by-products.
\end{abstract}

Keywords: palm oil, triunsaturated triacylglycerol, unsaturated fatty acid, enzymatic directed interesterification, response surface methodology.

Date received: 11 April 2018; Sent for revision: 12 April 2018; Received in final form: 10 July 2018; Accepted: 25 July 2018.

* Malaysian Palm Oil Board, 6 Persiaran Institusi, Bandar Baru Bangi, 43000 Kajang, Selangor, Malaysia. E-mail: nlida@mpob.gov.my

** Department of Food Technology, Faculty of Food Science and Technology, Universiti Putra Malaysia, 43400 UPM Serdang, Selangor, Malaysia.

₹ School of Science, Monash University Malaysia, Jalan Lagoon Selatan, Bandar Sunway, 47500 Subang Jaya, Selangor, Malaysia.

扯 Department of Bioprocess Technology, Faculty of Biotechnology and Biomolecular Sciences, Universiti Putra Malaysia, 43400 UPM Serdang, Selangor, Malaysia.

\section{INTRODUCTION}

Monounsaturated fatty acids (MUFA), especially oleic acid (C18:1), are often regarded as healthy dietary fatty acids that can confer substantial health benefits, as compared to polyunsaturated (PUFA) and saturated (SAFA) fatty acids. Many studies indicate that MUFA as the predominant form of fatty acid promoted a healthy lipid profile and reduced plasma total cholesterol, low-density lipoprotein (LDL) cholesterol and triacylglycerol (TAG) levels 
(Alvizouri-Muñoz et al., 1992; Gillingham et al., 2011; Schwingshackl and Hoffmann, 2012), thus offers significant protection against coronary heart disease/cardiovascular disease ( $\mathrm{Hu}$ and Willett, 2002). A MUFA-enriched diet also displayed beneficial effects on glucose metabolism, by improving insulin action and lowering blood glucose levels (Gillingham et al., 2011; Qian et al., 2016; Sartorius et al., 2012; Schwingshackl et al., 2011), may play a protective role against mild cognitive impairment and, ultimately, dementia (Naqvi et al., 2011; Vercambre et al., 2010), and showed anti-inflammatory effects (Galland, 2010). As for guidelines for MUFA consumption, the Academy of Nutrition and Dietetics, as well as the Canadian Dietetic Association, both encourage the consumption of $<25 \%$ MUFA, while the American Heart Association sets a limit of 20\% (Schwingshackl and Hoffmann, 2012).

MUFA are commonly found in liquid vegetable oils. Among the richest sources of MUFA are olive oil, high oleic sunflower oil and high oleic soyabean oil. Palm oil (PO) which is extracted from oil palm fruit's mesocarp is also rich in MUFA. PO consists of almost $50 \%$ of unsaturated fatty acids (USAFA), mainly in the form of oleic acid. The oleic acid content of PO is around $37.3 \%-40.8 \%$ of the total PO fatty acids (Kushairi et al., 2018; Noor Lida et al., 2002; O'Brien, 2009), and is mainly in the form of POO and POP TAG molecules, where $O$ is oleic acid and $P$ is palmitic acid. Fractionation of $P O$ results in two distinct fractions: the liquid fraction called palm olein (POo) and the solid fraction called palm stearin (POs). POO and other low-melting triunsaturated $\left(\mathrm{U}_{3}\right)$ TAG such as LOO/OLO, LLO/LOL and OOO (where $L$ is linoleic acid) is concentrated in the POo fraction. However, POo also contains a high amount of disaturated-monounsaturated $\left(S_{2} U\right)$ TAG, namely POP, PLP and POS, where $S$ is stearic acid.

Looking at the fatty acid composition, it seems possible to restructure the TAG molecules of PO for a higher amount of $\mathrm{U}_{3}$ TAG, especially $\mathrm{OOO}$ and OOL/OLO, which can later be concentrated in the POo fraction upon fractionation. About $6.4 \%-8.4 \%$ of $\mathrm{U}_{3}$ TAG are present naturally in PO (Noor Lida et al., 2002; Siew, 2011). Modification of the TAG structure of PO to increase its $\mathrm{U}_{3}$ TAG content, and, consequently, USAFA (especially the MUFA content in the POo fraction) is possible by interesterification (IE). IE, either chemical or enzymatic (EIE), is a process of rearranging the fatty acids within and between TAG molecules, leading to a variety of TAG species (Rozendaal, 1990). In general, IE is performed at a temperature higher than the melting point of the highest melting TAG component of the fat mixture, with the help of a chemical or enzymatic catalyst. IE can be random, specific or directed. Based on the law of probability, random IE, either chemical or enzymatic, leads to randomisation of fatty acids on the TAG molecules (Going, 1967; Klemann et al., 1994; Rozendaal, 1992). Specific IE is normally catalysed by an enzyme, i.e. lipase. Different categories of specific lipases have been identified, including positional specific ( $s n-1,3$ and sn-2 specific) and fatty acid-specific lipases (Cowan, 2013). Using specific lipases, full randomisation of fatty acids within or between TAG molecules can be avoided, thus producing TAG with a specific structure. In the case of $\mathrm{PO}, \mathrm{IE}$, either random or specific, only leads to small changes in the TAG composition. Restructuring of the TAG molecules of $\mathrm{PO}$, especially for a higher content of $\mathrm{U}_{3}$ TAG (particularly OOO) is made possible via directed IE (DIE).

DIE is performed at a temperature just below the melting point of the highest melting TAG, normally below $50^{\circ} \mathrm{C}$ (De Lathauwer et al., 1981). DIE is initialised by melting the oils and fats before addition of a catalyst to expedite the reaction. Subsequently, the DIE temperature is reduced to a level that is low enough for the highest melting TAG, typically $S_{3} T A G$, to crystallise out as they are formed. The high melting TAG are then withdrawn from the reaction phase (liquid phase) because when TAG crystallise, they are in the solid phase and can no longer play a part in the DIE reaction. To re-establish the reaction equilibrium, new high melting TAG are continuously being formed in the remaining liquid phase, which in turn also crystallise as a precipitate. The high melting TAG continue to form and crystallise until all TAG that can enter the solid phase are removed from the reaction. The segregation of SAFA into high melting TAG is in tandem with a tendency for USAFA to form very low melting (typically $\mathrm{U}_{3}$ ) TAG. DIE eventually results in a liquid phase that has become much less saturated as it is rich in very low melting TAG, and a solid phase that is rich in high melting TAG (Boot et al., 1984; Hawley and Holman, 1956; Huyghebaert et al., 1994; Placek and Holman, 1957; Rousseau and Marangoni, 2008). Hence, with DIE, $\mathrm{U}_{3}$ TAG in PO can be increased, which consequently improves USAFA content (especially MUFA) in POo fractions. The rearrangement of the TAG structure of PO via DIE may end up with a mixture that is rich in $\mathrm{U}_{3}$ TAG especially $\mathrm{OOO}$ and OOL/OLO and $\mathrm{S}_{3}$ TAG particularly tripalmitin (PPP), which can be separated out later by fractionation into the POo fraction which is high in oleic acid and the POs fraction which is rich in palmitic acid.

DIE can be carried out via a chemical (Lago and Hartman, 1986) or an enzymatic (MacKenzie and Stevenson, 2000) route. The main advantage of enzymatic over the chemical route is that the former is a 'green' and an environment-friendly process. Similar to other enzymatic IE processes, the efficiency of enzymatic DIE (EDIE) is influenced by several factors, such as the fat mixture composition, 
type of enzyme, enzyme load, reaction time, reaction temperature and moisture content. This study was thus conducted to study and optimise the processing parameters for EDIE of PO to produce a maximum yield of $\mathrm{U}_{3}$ TAG with a tolerable, if not a minimum, level of by-products, i.e. a mixture of free fatty acids (FFA), monoacylglycerols (MAG) and diacylglycerols (DAG), using response surface methodology (RSM). RSM is a collection of mathematical and statistical models used to develop, improve and optimise a product or process that requires only a minimum number of experimental runs as compared to the conventional single factor design (Bas and Boyac1, 2007). RSM enables an evaluation of the effects of multiple parameters, either alone or when interacting with each other, on response variables. The main advantage of RSM is that with a minimum number of experimental runs, it can provide sufficient information for statistically acceptable results (Mu et al., 1998). The predictive models derived from the statistical analysis of the experiment can then be utilised to construct the response surface curves for each of the selected responses. Analysis of the response surface curves allows for the identification of the optimum process parameters (Martinčič et al., 2008).

This study is of significance as information on DIE, especially on EDIE of PO is scarce. Information on the utilisation of RSM to determine the optimum EDIE conditions for a maximum $\mathrm{U}_{3}$ TAG yield from EDIE of PO is also not available. Hence, the present study aimed to optimise the reaction conditions of EDIE of $\mathrm{PO}$, namely reaction time, reaction temperature and enzyme load in order to obtain maximum yield of $\mathrm{U}_{3}$ TAG using RSM.

\section{MATERIALS AND METHODS}

\section{Materials}

Refined, bleached and deodorised (RBD) PO was procured from Keck Seng (M) Berhad (Masai, Johor, Malaysia). Commercial immobilised Lipozyme TLIM Thermomyces lanuginosus lipase was purchased from Novozymes A/S (Bagsvaerd, Denmark). The TAG standards used for elucidation of the TAG species were purchased from Sigma Aldrich Inc. (Sigma Chemical Co., USA). All chemicals and solvents were of analytical and high performance liquid chromatography (HPLC) grades, respectively.

\section{Methods}

Response surface methodology experimental design. Design Expert 10.0.3.1 software (StatEase Inc, Minnesota, USA) was used to optimise $\mathrm{U}_{3}$ TAG yield and minimise the amount of byproducts formed during EDIE of PO catalysed by Lipozyme TLIM lipase. Three factors and five levels central composite design (CCD), comprising 20 experimental runs and six replicates at the centre point, were used. The independent variables studied included reaction time $(A)$, reaction temperature $(B)$ and enzyme load $(C)$. The experiment variables in coded and actual units are shown in Table 1. The response variables were $\mathrm{U}_{3}$ TAG and by-products yields. The $\mathrm{U}_{3}$ TAG and by-products yields were analysed using HPLC with an evaporative lightscattering detector (ELSD).

The 20 experimental runs were performed at random. Analysis of variance (ANOVA) and multiple regression analysis with backward elimination at a 95\% significance level $(\mathrm{p}<0.05)$ were used to evaluate the data obtained from the experiments. The data fitted well with the secondorder regression equation shown below, where $Y$ represents the responses which are $\mathrm{U}_{3}$ TAG and by-products yields, $\beta_{0}$ is the intercept, while $\beta_{\mathrm{i}}, \beta$ and $\beta_{\mathrm{ij}}$ are the linear, quadratic, and the interaction coefficients, respectively. $X_{i}$ and $X_{j}$ are the levels of independent variables.

$$
Y=\beta_{0}+\sum_{i=1}^{3} \beta_{i} X_{i}+\sum_{i=1}^{3} \beta_{i i} X_{i}^{2}+\sum_{i=1}^{2} \sum_{j=i+1}^{3} \beta_{i j} X_{i} X_{j}
$$

Contour and three-dimensional response surface plots were created to demonstrate the relationships between the independent variables and responses. Subsequently, numerical optimisation was used to locate the 'sweet spot' for the responses of interest.

Lipozyme TLIM lipase conditioning. Lipozyme TLIM lipase was chosen as the catalyst in this study as it is commonly used for the enzymatic IE reaction, is low-priced, of food grade and possesses high IE activity (Lee et al., 2015; Zhang, 2007). The Lipozyme TLIM lipase was pre-conditioned to eliminate extra moisture before the EDIE reaction was conducted.

TABLE 1. EXPERIMENT VARIABLES IN CODED AND ACTUAL UNITS

\begin{tabular}{|c|c|c|c|c|c|c|}
\hline Independent variable & Symbol & \multicolumn{5}{|c|}{ Coded variable } \\
\hline Reaction time (hr) & A & 12.0 & 15.0 & 20.0 & 25.0 & 28.0 \\
\hline Reaction temperature $\left({ }^{\circ} \mathrm{C}\right)$ & $\mathrm{B}$ & 20.0 & 25.0 & 35.0 & 45.0 & 50.0 \\
\hline Enzyme load (w/w \%) & C & 2.0 & 5.0 & 10.0 & 15.0 & 18.0 \\
\hline
\end{tabular}


Water, approximately 5\% (w/w) in immobilised enzyme, has to be removed to prevent hydrolysis of the oil substrate as well as to prevent FFA and partial glycerides such as MAG and DAG from forming (Saw and Siew, 2014). Lipozyme TLIM lipase was conditioned by reacting the lipase $(10 \% \mathrm{w} / \mathrm{w})$ with $\mathrm{PO}$ at $70^{\circ} \mathrm{C}$ for $30 \mathrm{~min}$ before draining the $\mathrm{PO}$ from the reaction system. This step was repeated five times with fresh RBD PO. After the fifth reaction, PO contained only about 3.0\% FFA compared with $18 \%$ FFA in PO from the initial reaction. The FFA was assessed by a titration method defined in the AOCS Official Method Ca 5a-40 (Firestone, 2009). The FFA was expressed as the percentage of palmitic acid. The treated enzyme was then used for the subsequent EDIE reaction.

Enzymatic directed interesterification of palm oil. Accurately weighed moisture-free PO was melted at $80^{\circ} \mathrm{C}$ for $45 \mathrm{~min}$ under vacuum in a temperature-controlled stirred vessel. The oil temperature was then reduced to the selected reaction temperature. The reaction was initialised following the addition of the pre-conditioned Lipozyme TLIM lipase once the desired reaction temperature was reached. When the desired reaction time was achieved, the reaction was stopped by rapidly heating the reaction mixture to a high temperature in a microwave oven. The desired reaction temperature, enzyme load and reaction time were in accordance with the RSM design. The mixture containing the melted EDIE $\mathrm{PO}$ and enzyme was then quickly vacuum-filtered to remove the enzyme. The EDIE PO samples were kept at $-20^{\circ} \mathrm{C}$ for further analysis.

Triacylglycerol composition. TAG composition was measured using Waters HPLC Model Alliance e2695 (Waters, United Kingdom), which was equipped with Waters ELSD model ELSD 2424. A Merck KGaA column (Darmstadt, Germany) Purospher ${ }^{\circledR}$ Star RP-18e $(250 \mathrm{~mm} \times 4 \mathrm{~mm})$ with $5 \mu \mathrm{m}$ particle size was used to separate out the TAG. Column temperature was set at $35^{\circ} \mathrm{C}$. The samples were first melted at $70^{\circ} \mathrm{C}$ and dissolved in acetone at a concentration of $10 \%(\mathrm{v} / \mathrm{v})(100 \mu \mathrm{l}$ of sample into $900 \mu \mathrm{l}$ of acetone), and then passed through a $0.2 \mu \mathrm{m}$ PTFE membrane filter to remove impurities. The $10 \mu \mathrm{l}$ samples were then injected into the column. Separation was carried out with a mobile phase containing a mixture of acetone and acetonitrile (Merck, Darmstadt, Germany) at a gradient composition of 35\%:65\%, 65\%:35\%, $85 \%: 15 \%, 35 \%: 65 \%$ and $35 \%: 65 \%$ of acetone: acetonitrile for $0,10,15,20$ and $25 \mathrm{~min}$, respectively. The mobile phase flow rate was set at $1.5 \mathrm{ml} \mathrm{min}^{-1}$ with a total run time of $25 \mathrm{~min}$. Individual TAG (OLL, OLO, OOO, PLL, PLO, POO, SOO, PLP, POP, POS, PMP, PPP and PPS) peaks were identified by comparing the peaks elution times with those of pure TAG standards, and quantified using the peak area normalisation method.

By-products (free fatty acid, monoacylglycerol and diacylglycerol) quantification. Quantification of the by-products (FFA, MAG and DAG) in the EDIE PO was done by subtracting the total TAG area (\%) from the total chromatogram area $(100 \%)$. The TAG was quantified according to the method described earlier.

\section{RESULTS AND DISCUSSION}

\section{Screening of the Range of Enzymatic Directed Interesterification Reaction Parameters}

Before performing RSM, screening of the important parameters affecting the EDIE reaction, namely the reaction temperature, reaction time and enzyme load, was executed to determine the operational and range of interest for the formation of $\mathrm{U}_{3}$ TAG. Reaction temperature in the range of $25^{\circ} \mathrm{C}-45^{\circ} \mathrm{C}$ was chosen for the RSM design as it was observed that EDIE did not take place efficiently if the reaction temperature was too low $\left(<25^{\circ} \mathrm{C}\right)$ or too high $\left(>45^{\circ} \mathrm{C}\right)$. It was found that when enzyme load and reaction temperature were fixed, $\mathrm{U}_{3}$ TAG yield was the highest when reaction temperature was around $25^{\circ} \mathrm{C}-35^{\circ} \mathrm{C}$. Reaction time of $15-25 \mathrm{hr}$ was selected for the RSM design as it was observed that even though total $U_{3}$ TAG increased as reaction time was prolonged, extending the reaction time also increased the by-products. A high amount of by-products is not desirable. Shorter reaction time $(<15 \mathrm{hr})$ on the other hand resulted in a too low yield of $\mathrm{U}_{3}$ TAG. Enzyme load of $5 \%-15 \%$ was chosen as the Lipozyme TLIM lipase works well in this range. Enzyme load of $15 \%$ was set as the maximum limit because a higher enzyme load did not have much of an effect on $\mathrm{U}_{3}$ TAG yield, and, at the same time, it also incurred a higher operational cost. An example of the amounts of $\mathrm{U}_{3} \mathrm{TAG}$ and by-products produced throughout the $72 \mathrm{hr}$ of EDIE of PO in the presence of $10 \%$ Lipozyme TLIM lipase at $30^{\circ} \mathrm{C}$ is shown in Figure 1. It was observed that the increase in $\mathrm{U}_{3}$ TAG yield occurred simultaneously with an increase in $\mathrm{S}_{3}$ TAG and by-product yields and at the expense of $\mathrm{U}_{2} \mathrm{~S}$ and $\mathrm{S}_{2} \mathrm{U}$ TAG that were initially present in high amounts in $\mathrm{PO}$.

\section{Model Fitting}

CCD of five levels and three factors was adopted to determine $\mathrm{U}_{3}$ TAG and by-products yields. CCD for the 20 experimental runs and data for two responses, namely $\mathrm{U}_{3}$ TAG and by-products yields, are shown in Table 2. 


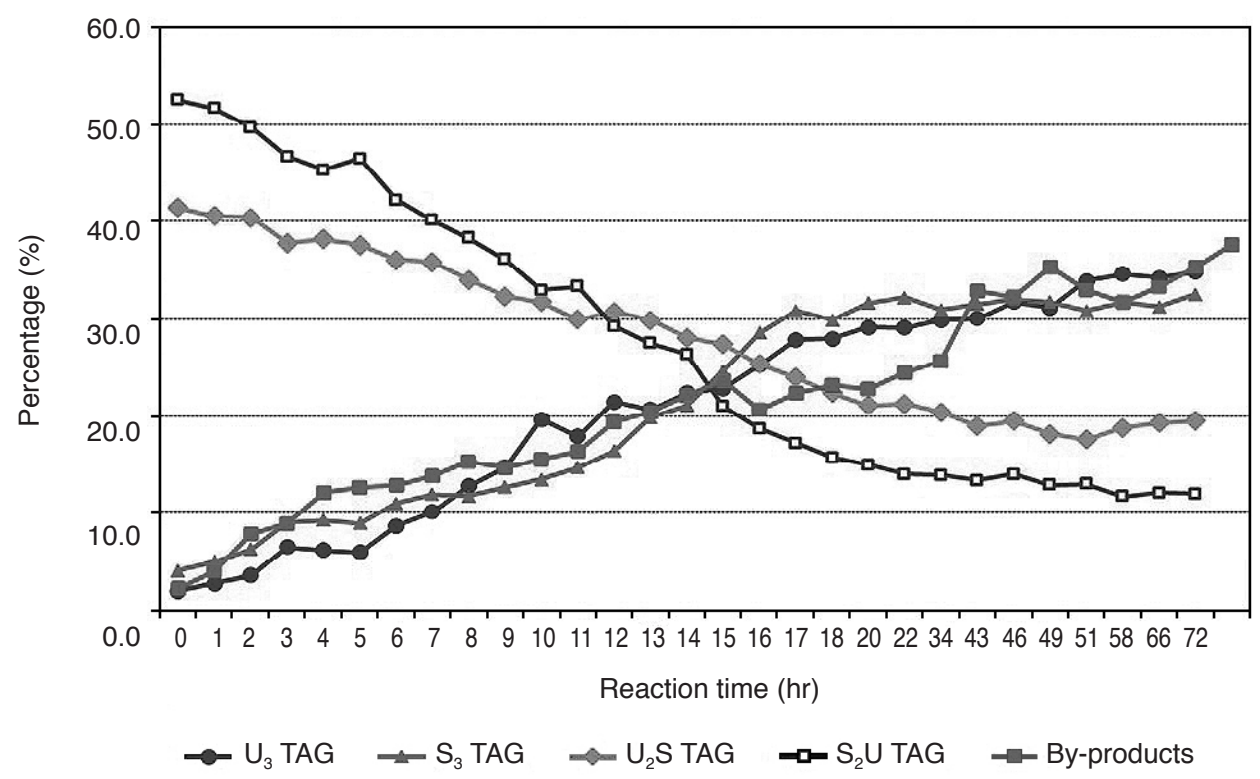

Note: TAG - triacylglycerol.

Figure 1. Amounts of triunsaturated $\left(U_{3}\right)$, diunsaturated-monosaturated $\left(U_{2} S\right)$, monounsaturated-disaturated $\left(S_{2} U\right)$, trisaturated $\left(S_{3}\right)$ triacylglycerols and by-products (free fatty acids, monoacylglycerols and diacylglycerols) throughout the $72 \mathrm{hr}$ of enzymatic directed interesterification of palm oil produced in the presence of $10 \%$ Lipozyme TLIM lipase at $30^{\circ} \mathrm{C}$.

TABLE 2. CENTRAL COMPOSITE DESIGN FOR 20 EXPERIMENTAL RUNS AND DATA FOR TWO RESPONSES, NAMELY TRIUNSATURATED TRIACYLGLYCEROLS AND BY-PRODUCTS (free fatty acids, monoacylglycerols and diacylglycerols) YIELDS

\begin{tabular}{|c|c|c|c|c|c|c|}
\hline \multirow{2}{*}{ Std } & \multirow{2}{*}{ Run } & \multicolumn{3}{|c|}{ Independent variable } & \multicolumn{2}{|c|}{ Response } \\
\hline & & A & B & $\mathrm{C}$ & $\mathrm{U}_{3}$ TAG $(\%)$ & By-products $(\%)$ \\
\hline 4 & 1 & 25.0 & 45.0 & 5.0 & 9.4 & 30.8 \\
\hline 10 & 2 & 28.0 & 35.0 & 10.0 & 26.8 & 33.4 \\
\hline 1 & 3 & 15.0 & 25.0 & 5.0 & 7.3 & 20.7 \\
\hline 12 & 4 & 20.0 & 50.0 & 10.0 & 5.8 & 32.1 \\
\hline 8 & 5 & 25.0 & 45.0 & 15.0 & 17.9 & 34.2 \\
\hline 19 & 6 & 20.0 & 35.0 & 10.0 & 27.9 & 26.8 \\
\hline 18 & 7 & 20.0 & 35.0 & 10.0 & 29.0 & 24.3 \\
\hline 13 & 8 & 20.0 & 35.0 & 2.0 & 7.8 & 23.8 \\
\hline 2 & 9 & 25.0 & 25.0 & 5.0 & 12.8 & 27.4 \\
\hline 5 & 10 & 15.0 & 25.0 & 15.0 & 23.2 & 18.3 \\
\hline 14 & 11 & 20.0 & 35.0 & 18.0 & 28.8 & 28.7 \\
\hline 16 & 12 & 20.0 & 35.0 & 10.0 & 27.4 & 25.6 \\
\hline 17 & 13 & 20.0 & 35.0 & 10.0 & 28.0 & 24.1 \\
\hline 7 & 14 & 15.0 & 45.0 & 15.0 & 12.8 & 20.6 \\
\hline 6 & 15 & 25.0 & 25.0 & 15.0 & 30.3 & 30.1 \\
\hline 11 & 16 & 20.0 & 20.0 & 10.0 & 20.2 & 24.3 \\
\hline 15 & 17 & 20.0 & 35.0 & 10.0 & 29.7 & 25.9 \\
\hline 3 & 18 & 15.0 & 45.0 & 5.0 & 7.8 & 21.8 \\
\hline 9 & 19 & 12.0 & 35.0 & 10.0 & 18.1 & 20.1 \\
\hline 20 & 20 & 20.0 & 35.0 & 10.0 & 27.8 & 23.8 \\
\hline
\end{tabular}

Note: A - reaction time $(\mathrm{hr}), \mathrm{B}$ - reaction temperature $\left({ }^{\circ} \mathrm{C}\right), \mathrm{C}$ - enzyme load $(\mathrm{w} / \mathrm{w} \%), \mathrm{U}_{3}$ TAG - triunsaturated triacylglycerols.

The best-fitting models were analysed through multiple linear regression with backward elimination in which factors and interactions that were not significant were removed from the models. Out of the four models, namely linear, two-level factorial, quadratic and cubic, EDIE for $\mathrm{U}_{3}$ TAG yield fitted well with the quadratic model (modified model). By-products yield fitted best with the linear model. The goodness of fit model was determined by the coefficient of determination, the $\mathrm{R}^{2}$. While a good model has a high $\mathrm{R}^{2}$, depending only on the value of regular $R^{2}$ can lead to poor prediction. The $R^{2}$ increases when more variables are added to the model, whether or not these variables are statistically significant. Thus, better predictions are made by considering both the adjusted $-\mathrm{R}^{2}$ and 
predicted- $\mathrm{R}^{2}$ values (Lee et al., 2015). However, the adjusted- $\mathrm{R}^{2}$ and the predicted- $\mathrm{R}^{2}$ plateau when too many insignificant variables are added to the model. The rule of thumb to follow is that the difference between the adjusted- $R^{2}$ and predicted- $R^{2}$ values should be not more than 0.2 . The values of $\mathrm{R}^{2}$, adjusted- $\mathrm{R}^{2}$ and predicted- $\mathrm{R}^{2}$ for $\mathrm{U}_{3} \mathrm{TAG}$ and byproducts yields were $0.9911,0.9831$ and 0.9475 , and $0.8733,0.8495$ and 0.7865 , respectively. The difference between the adjusted- $R^{2}$ and predicted- $R^{2}$ values for $\mathrm{U}_{3}$ TAG and by-products yields was less than 0.2 . The F-values of the models were 123.97 for $\mathrm{U}_{3}$ TAG yield and 36.75 for by-products yield, implying that both models were significant. The model terms are significant when the value of 'Probability $>F^{\prime}$ ' is less than 0.05 while values higher than 0.05 show insignificant model terms. In the case of $\mathrm{U}_{3} \mathrm{TAG}$ yield, $\mathrm{A}, \mathrm{B}, \mathrm{C}, \mathrm{BC}, \mathrm{A}^{2}, \mathrm{~B}^{2}, \mathrm{C}^{2}$, and, in the case of byproducts, $A, B$ were significant model terms, where $A$ represents reaction time, $B$ reaction temperature and $C$ enzyme load. The quadratic model for $\mathrm{U}_{3} \mathrm{TAG}$ yield and the linear model for by-products yield had a lack of fit F-value of 2.64 and 2.76, respectively, which imply that the lack of fit was not significant $(p>0.05)$. The ANOVA for $\mathrm{U}_{3} \mathrm{TAG}$ and by-products yields are shown in Tables 3 and 4, respectively. The ANOVA data showed that both the quadratic model with backward elimination and the linear model were highly significant and sufficient to show the relationship between both responses and the variables in this study. An equation expressed in terms of coded factors can be utilised for predicting the response for any given level of a factor. The equation is also useful for identifying the relative impact of each factor by comparing the factor coefficients. The second order coded equations for $\mathrm{U}_{3} \mathrm{TAG}$ and by-products yields are as follows:

$$
\begin{aligned}
& \mathrm{Y}_{\mathrm{U}_{3} \text { TAG Yield }}=+28.38+2.53 \mathrm{~A}-3.71 \mathrm{~B}+6.14 \mathrm{C}- \\
& 2.49 \mathrm{BC}-2.52 \mathrm{~A}^{2}-6.21 \mathrm{~B}^{2}-4.14 \mathrm{C}^{2} \\
& \mathrm{Y}_{\text {by-products Yield }}=+25.84+4.75 \mathrm{~A}+1.78 \mathrm{~B}+0.79 \mathrm{C}
\end{aligned}
$$

Degree of Three Parameters on Enzymatic Directed Interesterification Reaction of Palm Oil for Triunsaturated Triacylglycerol Production

The ANOVA of quadratic model representing $\mathrm{U}_{3}$ TAG yield from EDIE of $\mathrm{PO}$ are shown in Table 3. All three factors, namely reaction time, reaction temperature and enzyme load, significantly affected $\mathrm{U}_{3}$ TAG yield. The formation of $\mathrm{U}_{3} \mathrm{TAG}$ was positively influenced by reaction time and enzyme load, while negatively influenced by reaction temperature. Increase in time and enzyme load increased the $\mathrm{U}_{3}$ TAG yield but increase in the reaction temperature above $35^{\circ} \mathrm{C}$ reduced the $\mathrm{U}_{3}$ TAG yield. All factors had a significant effect on $U_{3}$ TAG yield, with a p-value of $<0.0001(\mathrm{p}<0.05)$. This finding is in agreement with the findings of Cao et al. (2013), Öztürk et al. (2010) and $\mathrm{Xu}$ et al. (1998). There was a higher reaction conversion rate with a higher amount of lipase, which is in agreement with the findings of Cao et al. (2013) and Paula et al. (2016). In most enzymatic IE reactions, enzyme mainly speeds up the reaction and does not affect the conversion rate, as reported by Lee $e t$ al. (2015). However, in the case of batch EDIE of PO, the accumulation of $S_{3}$ TAG particularly PPP might have slowed down the enzyme activity especially when the enzyme load was too low, thus resulting in a low yield of $\mathrm{U}_{3}$ TAG. From the 20 trial

\begin{tabular}{|c|c|c|c|c|c|}
\hline Source & $\begin{array}{l}\text { Sum of } \\
\text { squares }\end{array}$ & DF & $\begin{array}{c}\text { Mean } \\
\text { squares }\end{array}$ & $\begin{array}{c}\mathbf{F} \\
\text { value }\end{array}$ & $\begin{array}{l}\text { p-value } \\
\text { Prob }>\text { F }\end{array}$ \\
\hline Model & 1528.05 & 9 & 169.78 & 123.97 & $<0.0001$ \\
\hline B & 181.07 & 1 & 181.07 & 132.21 & $<0.0001$ \\
\hline $\mathrm{C}$ & 493.92 & 1 & 493.92 & 360.65 & $<0.0001$ \\
\hline $\mathrm{B}^{*} \mathrm{C}$ & 49.50 & 1 & 49.50 & 36.14 & 0.0001 \\
\hline $\mathrm{A}^{*} \mathrm{~A}$ & 78.71 & 1 & 78.71 & 57.47 & $<0.0001$ \\
\hline $\mathrm{B}^{\star} \mathrm{B}$ & 479.20 & 1 & 479.20 & 349.90 & $<0.0001$ \\
\hline $\mathrm{C}^{*} \mathrm{C}$ & 212.84 & 1 & 212.84 & 155.41 & $<0.0001$ \\
\hline Residual & 13.70 & 10 & 1.37 & NA & NA \\
\hline $\mathrm{R}^{2}$ & 0.9911 & - & - & - & - \\
\hline Adjusted-R ${ }^{2}$ & 0.9831 & - & - & - & - \\
\hline Predicted-R ${ }^{2}$ & 0.9475 & - & - & - & - \\
\hline
\end{tabular}

TABLE 3. ANOVA OF QUADRATIC MODEL REPRESENTING TRIUNSATURATED TRIACYLGLYCEROL YIELD FROM ENZYMATIC DIRECTED INTERESTERIFICATION OF PALM OIL

Note: A - reaction time (hr), B - reaction temperature $\left({ }^{\circ} \mathrm{C}\right), \mathrm{C}$ - enzyme load $(\mathrm{w} / \mathrm{w} \%)$; DF - degree of freedom, NA - not available. ANOVA - analysis of variance. 
runs (Table 2), the highest $\mathrm{U}_{3}$ TAG yield obtained was $30.3 \%$ at $25^{\circ} \mathrm{C}$ in the presence of $15 \%$ enzyme load and for a 25-hr reaction time. Meanwhile, the lowest yield obtained was $5.8 \%$ when the reaction time was $20 \mathrm{hr}$, the reaction temperature was $50^{\circ} \mathrm{C}$ and the enzyme load was $10.0 \%$. The relationship between reaction time and reaction temperature as well as the relationship between reaction time and enzyme load exhibited antagonistic effect on the $U_{3}$ TAG yield. Meanwhile, interaction between reaction temperature and enzyme load showed to have synergistic effect on the $\mathrm{U}_{3}$ TAG. As for by-products yield, it was significantly influenced by reaction time ( $p$-value $<0.0001$ ) and reaction temperature $(\mathrm{p}$-value $=0.0022)$, but not by enzyme load ( $\mathrm{p}$-value $=0.1268$ ). The ANOVA of linear model representing by-products yield from EDIE of PO is demonstrated in Table 4.

\section{Single Factor Response}

Figure 2 illustrates the perturbation graph of the effect of single factors on $\mathrm{U}_{3}$ TAG yield. Reaction time significantly affects the product yield in an enzymatic IE process; thus, there was a rise in $\mathrm{U}_{3}$ TAG yield when the reaction time of the EDIE of PO was increased. When the reaction temperature was fixed at $30^{\circ} \mathrm{C}$ and enzyme load at $10 \%, \mathrm{U}_{3}$ TAG yield reached its maximum point in about $20 \mathrm{hr}$. Any further increase in reaction time had little effect on $\mathrm{U}_{3}$ TAG yield, as the reaction might have reached its equilibrium state. These findings are in agreement with the findings of Chobanov and Topalova (1979) who reported that $U_{3}$ TAGyield inlard increased with a more extended reaction time of EDIE. $\mathrm{U}_{3}$ TAG yield in lard reached its maximum after approximately $18-20 \mathrm{hr}$ at a reaction temperature of $28^{\circ} \mathrm{C}$, with little increase in $\mathrm{U}_{3}$ TAG yield when the reaction time was extended. Similarly, in the case of EDIE of PO, a further increase in the reaction time after $\mathrm{U}_{3} \mathrm{TAG}$ yield had reached its maximum resulted in a small but progressive increase in $\mathrm{U}_{3}$ TAG yield. However, extended reaction time also led to the formation of a high amount of by-products, probably because of acyl migration, which is in agreement with the findings of Hamam and Budge (2010), Lee et al. (2015) and Zhang (2007). The extended reaction time may also lead to randomisation of FA in the glycerol backbone (Zhang, 2007).

Additionally, reaction temperature of EDIE PO was also a crucial factor that affected $U_{3}$ TAG yield. There was an increase in $\mathrm{U}_{3}$ TAG yield when reaction temperature was increased until it reached a saturation point. This finding is in agreement with that of $\mathrm{Mu}$ et al. (1998) who found that increased reaction temperature of enzymatic IE improved the production of specific structured TAG containing essential fatty acids and medium-chain fatty acids. The best reaction temperature for EDIE of PO for producing high $\mathrm{U}_{3} \mathrm{TAG}$ yield was between $25^{\circ} \mathrm{C}$ and $35^{\circ} \mathrm{C}$, with $30^{\circ} \mathrm{C}$ being the optimum temperature. Nevertheless, $U_{3}$ TAG yield started to decrease when reaction temperature was higher than $35^{\circ} \mathrm{C}$. Temperatures below $25^{\circ} \mathrm{C}$ and above $35^{\circ} \mathrm{C}$ resulted in a reduction in $\mathrm{U}_{3}$ TAG yield. According to Novozymes, the optimum reaction temperature for Lipozyme TLIM lipase is in the region of $20^{\circ} \mathrm{C}-50^{\circ} \mathrm{C}$. Usually, for IE of oils and fats, the optimum reaction temperature when Lipozyme TLIM is used as the catalyst is in the range of $50^{\circ} \mathrm{C}-75^{\circ} \mathrm{C}$, as reported by Elibal et al. (2011) and Zhang et al. (2001). A reaction temperature of EDIE PO that was too low reduced the lipase activity which subsequently led to a lower amount of $U_{3}$ TAG. An increase in reaction temperature above $35^{\circ} \mathrm{C}$ retarded the formation of $\mathrm{U}_{3}$ TAG. These findings agree with that of Placek and Holman (1957) who stated that an EDIE reaction must be carried out at a temperature below the melting point of the fat. The melting point of $\mathrm{PO}$ is about $35.6^{\circ} \mathrm{C}$ (Tarmizi et al., 2008). Similar results

TABLE 4. ANOVA OF LINEAR MODEL REPRESENTING BY-PRODUCTS (free fatty acids, monoacylglycerols and diacylglycerols) YIELD FROM ENZYMATIC DIRECTED INTERESTERIFICATION OF PALM OIL

\begin{tabular}{|c|c|c|c|c|c|}
\hline Source & $\begin{array}{l}\text { Sum of } \\
\text { squares }\end{array}$ & DF & $\begin{array}{c}\text { Mean } \\
\text { squares }\end{array}$ & $\begin{array}{c}\text { F } \\
\text { value }\end{array}$ & $\begin{array}{l}\text { p-value } \\
\text { Prob }>\text { F }\end{array}$ \\
\hline Model & 346.40 & 3 & 115.47 & 36.75 & $<0.0001$ \\
\hline B & 41.66 & 1 & 41.66 & 13.26 & 0.0022 \\
\hline $\mathrm{C}$ & 8.15 & 1 & 8.15 & 2.59 & 0.1268 \\
\hline Pure error & 7.11 & 5 & 1.42 & NA & NA \\
\hline Cor total & 396.67 & 19 & - & - & - \\
\hline $\mathrm{R}^{2}$ & 0.8733 & - & - & - & - \\
\hline Adjusted- $R^{2}$ & 0.8495 & - & - & - & - \\
\hline Predicted- $\mathrm{R}^{2}$ & 0.7865 & - & - & - & - \\
\hline
\end{tabular}

Note: A - reaction time $(\mathrm{hr}), \mathrm{B}$ - reaction temperature $\left({ }^{\circ} \mathrm{C}\right), \mathrm{C}$ - enzyme load $(\mathrm{w} / \mathrm{w} \%)$, DF - degree of freedom, ANOVA - analysis of variance. 


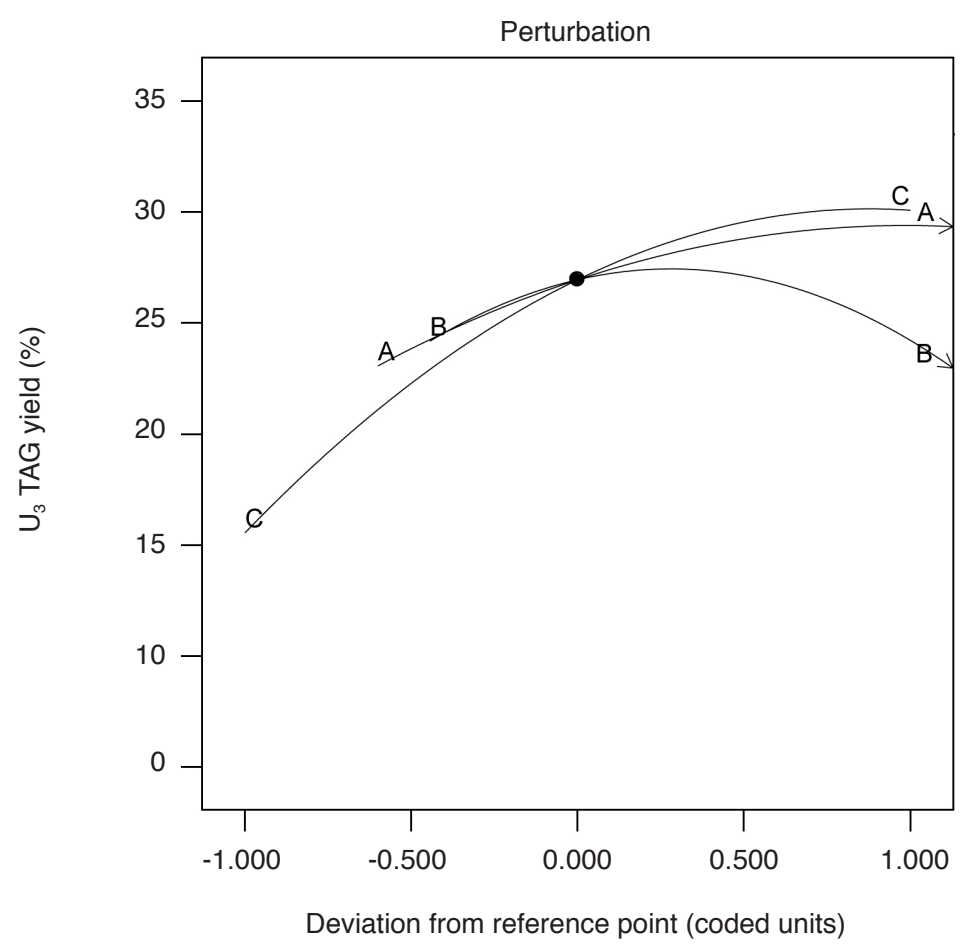

Note: A - reaction time, B - reaction temperature, C - enzyme load.

Figure 2. Perturbation graph showing the effect of single factors on triunsaturated triacylglycerols $\left(U_{3} T A G\right)$ yield.

have been reported by Chobanov and Topalova (1979) who found that to obtain a higher $\mathrm{U}_{3}$ TAG yield from EDIE of lard, EDIE was best carried out at about $28^{\circ} \mathrm{C}$. In the case of EDIE of PO, if the reaction was carried out at a temperature higher than $35^{\circ} \mathrm{C}$, it will not result in a high yield of $\mathrm{U}_{3} \mathrm{TAG}$ because the high reaction temperature will impede the precipitation of the high melting TAG that were formed during EDIE. As a result, the IE will be directed towards randomisation instead.

A higher amount of Lipozyme TLIM lipase stimulated the conversion of $\mathrm{S}_{2} \mathrm{U}$ and $\mathrm{U}_{2} \mathrm{~S}$ TAG to $\mathrm{U}_{3}$ TAG until it reached a saturation point at about $10 \%$ enzyme load. There was little change in $U_{3}$ TAG yield when enzyme load was increased from $10 \%$ to $18 \%(\mathrm{w} / \mathrm{w})$. This finding is in agreement with those of Cao et al. (2013) and Huang et al. (2010). Cao et al. (2013) found that the conversion of fatty acid methyl esters and the yield of $U_{3}$ TAG increased with the amount of lipase enzyme. Huang et al. (2010) showed that the optimum Lipozyme TLIM lipase load for obtaining the highest yield of lard-based biodiesel was $8 \%$ and that there was no significant increase in yield even when the additional enzyme was added. In contrast, Lee et al. (2015) reported that enzyme load was only responsible for speeding up the EIE reaction but had no effect on the yield of palm-based medium- and long-chain TAG. A low enzyme load, however, resulted in a lower conversion of $\mathrm{S}_{2} \mathrm{U}$ and $\mathrm{U}_{2} \mathrm{~S}$ TAG into $\mathrm{U}_{3} \mathrm{TAG}$. For example, a reaction time of $15 \mathrm{hr}$ and an enzyme load of $6 \%$ resulted in the formation of about $15.0 \% \mathrm{U}_{3} \mathrm{TAG}$, whereas when enzyme load was increased to $12.0 \%$, about $25.0 \%$ $\mathrm{U}_{3}$ TAG can be achieved.

FFA, MAG, and DAG were the by-products formed in this study. The by-products must be kept to a minimum at the end of the reaction in order to obtain a pure TAG mixture consisting of a high amount of $\mathrm{U}_{3}$ TAG. Figure 3 shows the perturbation graph of the effect of the single factors on by-products yield. Only two factors, i.e., reaction time and reaction temperature, significantly $(\mathrm{p}<0.05)$ affected by-products yield (Table 4). Based on the regression coefficient, by-products yield was strongly affected by reaction time followed by reaction temperature. The by-products yield significantly increased with reaction time. For example, at $10 \%$ enzyme load and a reaction temperature of $30^{\circ} \mathrm{C}$, by-products yield was $20.0 \%, 24.8 \%$, and $29.6 \%$ at a reaction time of 15,20 and $25 \mathrm{hr}$, respectively. The rise in the byproducts yield in relation to increases in reaction time was due to acyl migration. According to $\mathrm{Mu}$ et al. (1998), acyl migration created a major issue in a batch-wise IE reaction and resulted in a high yield of by-products. A high reaction substrate to enzyme ratio prolonged the time required by the reaction to reach equilibrium, and, consequently, resulted in acyl migration. It was observed that an increase in reaction temperature resulted in a modest but significant increase in by-products yield, which is in line with findings of Lee et al. (2015) and $\mathrm{Mu}$ et al. (1998). Mu et al. (1998) reported that raising 


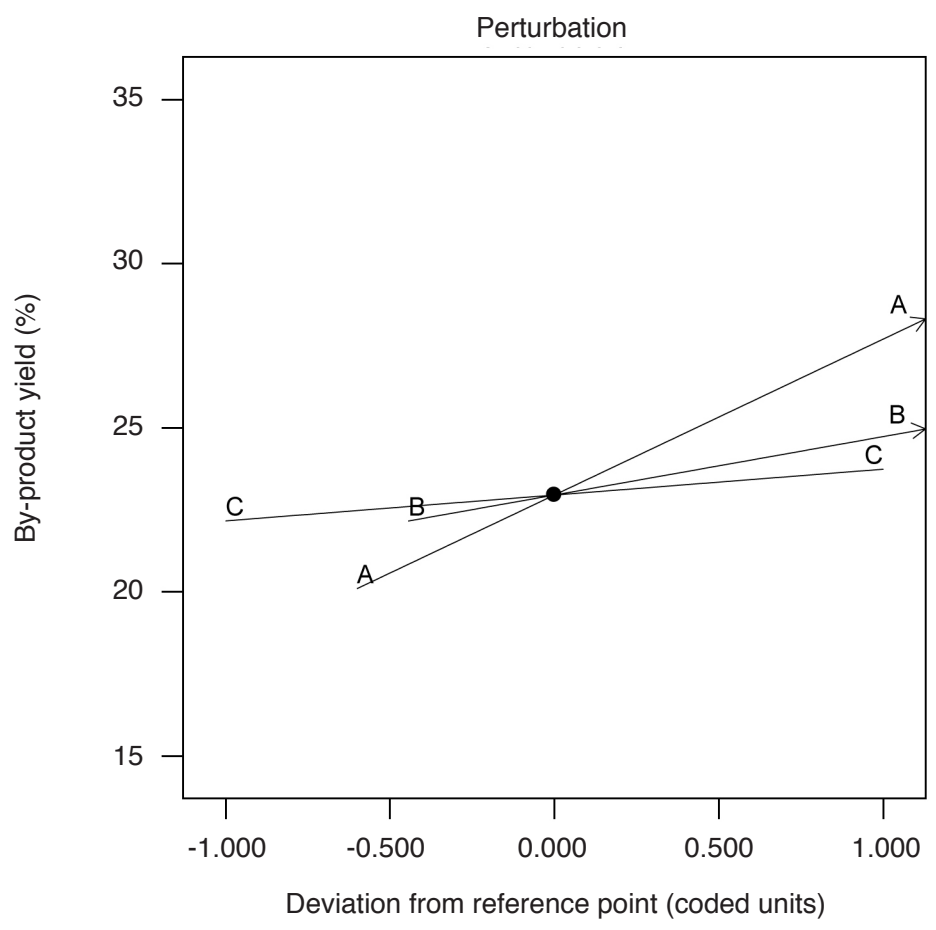

Note: A - reaction time, B - reaction temperature, C - enzyme load.

Figure 3. Perturbation graph showing the effect of single factors on total free fatty acids (FFA), monoacylglycerols (MAG) and diacylglycerols (DAG) [by-products] yield.

reaction temperature was followed by only a small increase in acyl migration which in turn resulted in lower by-products yield. A modest and insignificant increase in the by-products yield was also noticed when enzyme load was increased, which in turn may be due to the silica coating of the Lipozyme TLIM lipase that is hydrophilic, thus promoting a hydrolysis reaction. Hence, TAG is likely to be hydrolysed into either FFA, MAG, or DAG when the lipase enzyme is present in higher amounts (Lee et al., 2015).

\section{Relationship between the Reaction Parameters}

Figure 4 shows the contour and response surface plot of the effect of interaction between enzyme load and reaction time on $\mathrm{U}_{3}$ TAG yield. The response surface plot demonstrates that enzyme load played a significant role in the conversion of $\mathrm{S}_{2} \mathrm{U}$ and $\mathrm{U}_{2} \mathrm{~S}$ TAG to $U_{3}$ TAG. A higher enzyme load resulted in a higher conversion rate, whereby $\mathrm{U}_{3}$ TAG yield reached its maximum point within a shorter period. For instance, at an enzyme load of $14.0 \%, 28.0 \%$ of $\mathrm{U}_{3}$ TAG yield can be achieved in about $16.5 \mathrm{hr}$, as compared with $20 \mathrm{hr}$ at an enzyme load of $8.0 \%$. The higher conversion rate at higher enzyme load may be due to a higher availability of activation sites for the substrate to react, leading to a higher conversion rate of TAG to partial glycerides that are subsequently used as a substrate for $\mathrm{U}_{3}$ TAG formation. It was also observed that an enzyme load below 7\% did not have a significant effect on $\mathrm{U}_{3}$ TAG yield, even when the reaction time was extended. For example, at a $6 \%$ enzyme load, extending reaction time from 15 to $25 \mathrm{hr}$ only resulted in a 5\% increase in $\mathrm{U}_{3}$ TAG yield.

Figure 5 shows the contour and response surface plot of the relationship between reaction temperature and reaction time and how they affected $\mathrm{U}_{3} \mathrm{TAG}$ yield. At a high reaction temperature up to $35^{\circ} \mathrm{C}$, a shorter time was required for the reaction system to reach a higher yield of $\mathrm{U}_{3}$ TAG, indicating that the reaction equilibrium state was reached faster at a higher temperature. In turn, $\mathrm{U}_{3}$ TAG yield reached its maximum point faster at higher reaction temperatures, showing a higher conversion rate from $\mathrm{S}_{2} \mathrm{U}$ and $\mathrm{U}_{2} \mathrm{~S}$ TAG into $\mathrm{U}_{3}$ TAG. For example, the time taken to obtain a $\mathrm{U}_{3} \mathrm{TAG}$ yield of $28.0 \%$ at reaction temperatures of $27^{\circ} \mathrm{C}$ and $30^{\circ} \mathrm{C}$ was approximately 23 and $19 \mathrm{hr}$, respectively. This finding on the direct effect of reaction temperature on the reaction rate supports the theory of the Arrhenius equation which describes the temperature dependence of a reaction rate. Lee et al. (2015) and $\mathrm{Xu}$ et al. (1998) also observed similar results in their studies on the effect of reaction temperature and reaction time on specific structured lipids yield produced by EIE.

Figure 6 shows the contour response surface plot of the effect of the relationship between reaction temperature and enzyme load on $\mathrm{U}_{3}$ TAG yield. The contour plot shows that a high enzyme load up to about $17.0 \%$ and a high reaction temperature up to about $37.0^{\circ} \mathrm{C}$ resulted in a higher $\mathrm{U}_{3} \mathrm{TAG}$ yield of 


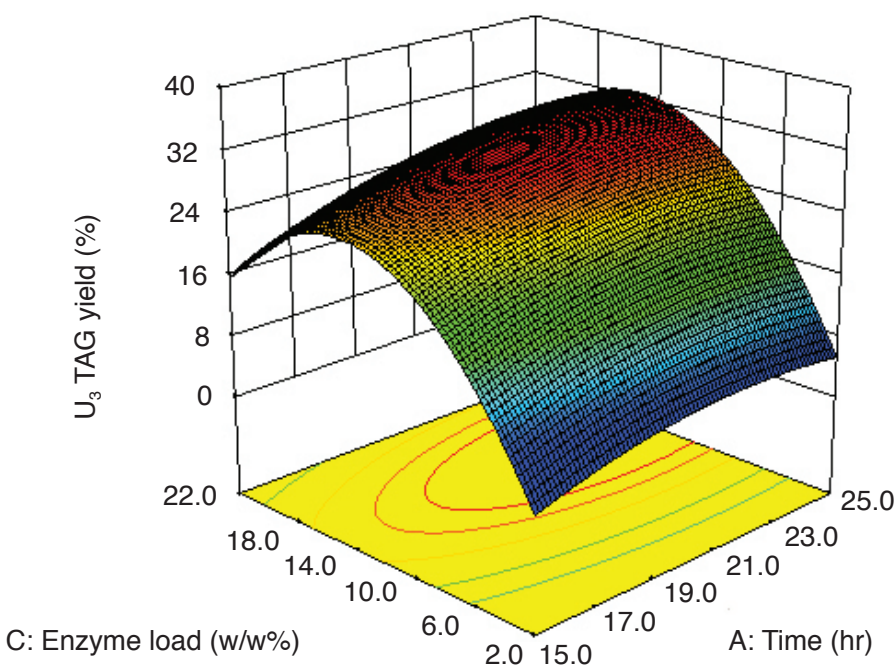

Figure 4. Contour and response surface plot showing the effect of interaction between enzyme load (w/w \%) and reaction time (hr) at a reaction temperature of $30^{\circ} \mathrm{C}$ on triunsaturated triglycerides $\left(U_{3} T A G\right)$ yield.

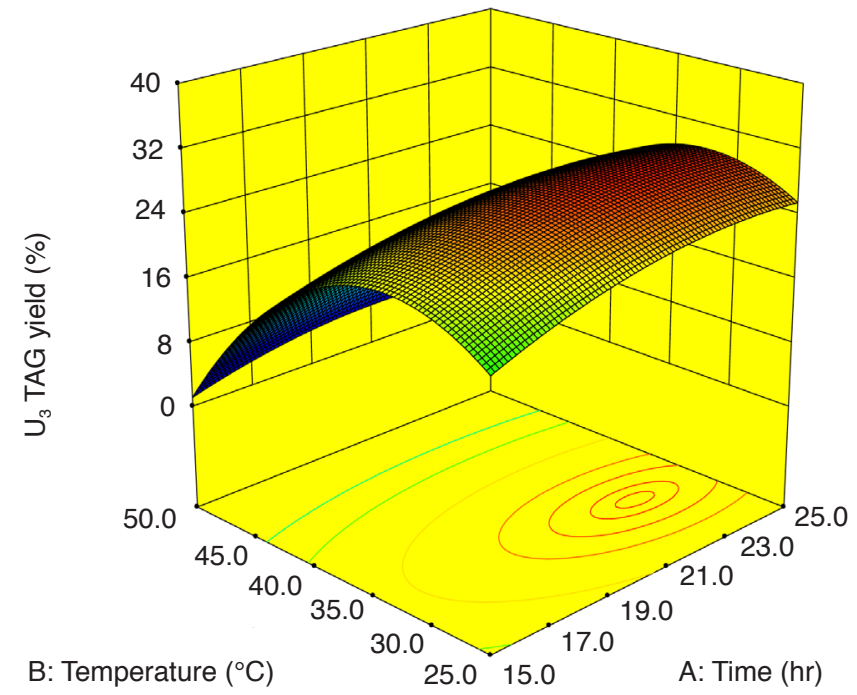

Figure 5. Contour and response surface plot showing the effect of interaction between reaction temperature $\left({ }^{\circ} \mathrm{C}\right)$ and reaction time ( $\left.h r\right)$ at enzyme load of $10 \%$ on triunsaturated triglycerides $\left(U_{3} T A G\right)$ yield.

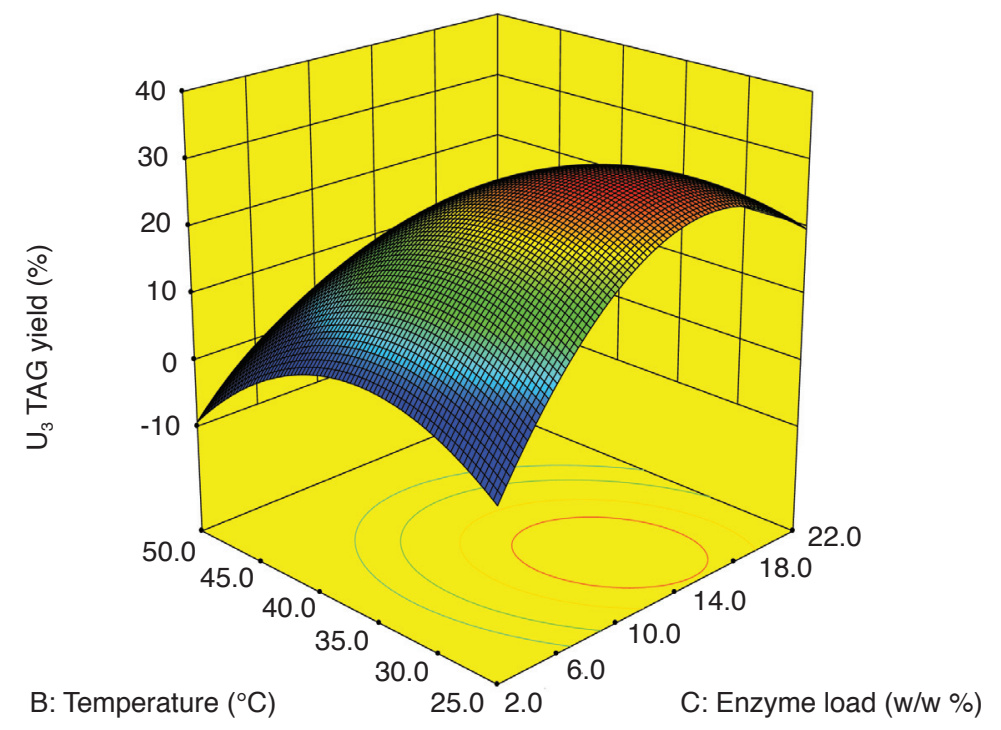

Figure 6. Contour and response surface plot showing the effect of interaction between enzyme load ( $w / w \%)$ and reaction temperature $\left({ }^{\circ} \mathrm{C}\right)$ at reaction time of $18 \mathrm{hr}$ on triunsaturated triglycerides $\left(U_{3}-T A G\right)$ yield. 
about $30.3 \%$. The conversion of $\mathrm{S}_{2} \mathrm{U}$ and $\mathrm{U}_{2} \mathrm{~S}$ TAG to $\mathrm{U}_{3}$ TAG was higher in the presence of a higher amount of Lipozyme TLIM lipase, at a reaction temperature range of $25.0^{\circ} \mathrm{C}$ to about $40.0^{\circ} \mathrm{C}$. At reaction temperatures above $40.0^{\circ} \mathrm{C}$, an increase in enzyme load did not have any significant effect on $\mathrm{U}_{3}$ TAG yield, which was less than $22.0 \%$ at a reaction temperature of more than $40.0^{\circ} \mathrm{C}$. It was also observed that at a high enzyme load, the maximum $\mathrm{U}_{3}$ TAG yield was achievable even at a considerably lower reaction temperature. For example, at $13 \%-17 \%$ enzyme load, $27.0 \% \mathrm{U}_{3}$ TAG yield was achieved at a reaction temperature of only $25.0^{\circ} \mathrm{C}$. These findings suggest that increasing the dosage of Lipozyme TLIM lipase and/or reaction temperature does not necessarily mean that a higher amount of $\mathrm{U}_{3}$ TAG can be attainable, as $\mathrm{U}_{3}$ TAG yield is also dependent on other processing parameters.

A clear interpretation of the effects of EDIE parameter interactions on by-products yield can be seen in the response contour plots in Figures 7 , 8 and 9. Figure 7 shows that a higher amount of by-products was formed when EDIE of PO was carried out at a higher reaction temperature and for a longer reaction time. A minimum amount of by-products can be achieved when the EDIE reactions were performed at lower temperatures, shorter reaction time and in the presence of less enzyme. Similar interaction trends were observed between reaction time and enzyme load (Figure 8 ), and between reaction temperature and enzyme load (Figure 9).

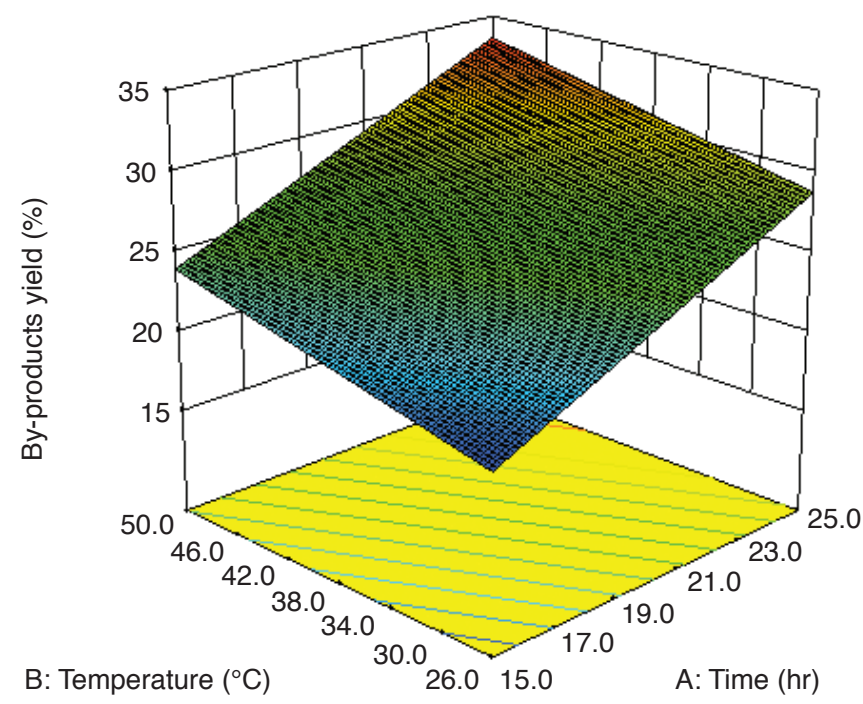

Figure 7. Contour and response surface plot of the effect of interaction between reaction temperature $\left({ }^{\circ} \mathrm{C}\right)$ and reaction time (hr) at $10 \%$ enzyme load on by-products (free fatty acids, monoacylglycerols and diacylglycerols) yield.

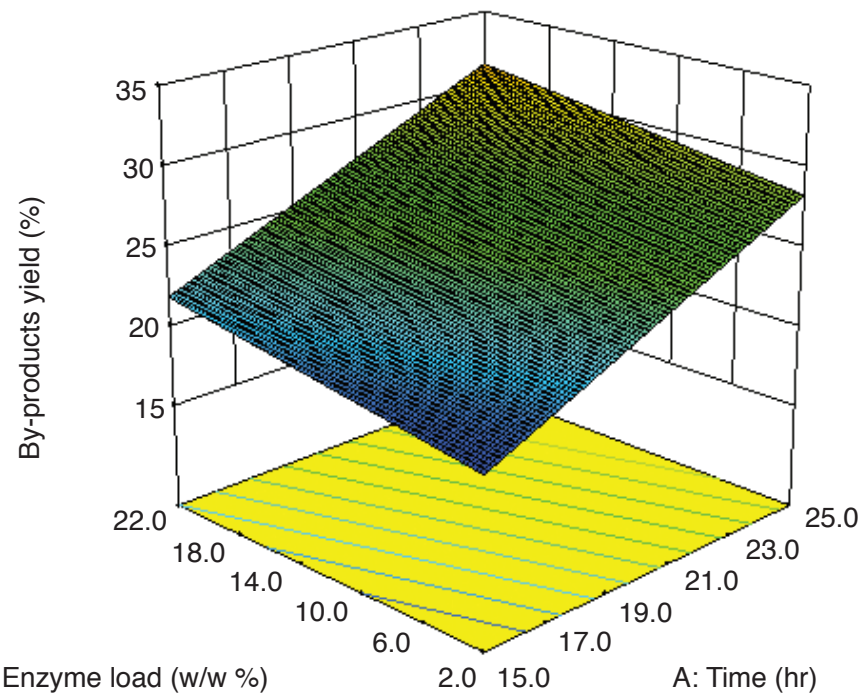

Figure 8. Contour and response surface plot of the effect of interaction between enzyme load (w/w \%) and reaction time (hr) at reaction temperature of $30^{\circ} \mathrm{C}$ on by-products (free fatty acids, monoacylglycerols and diacylglycerols) yield. 


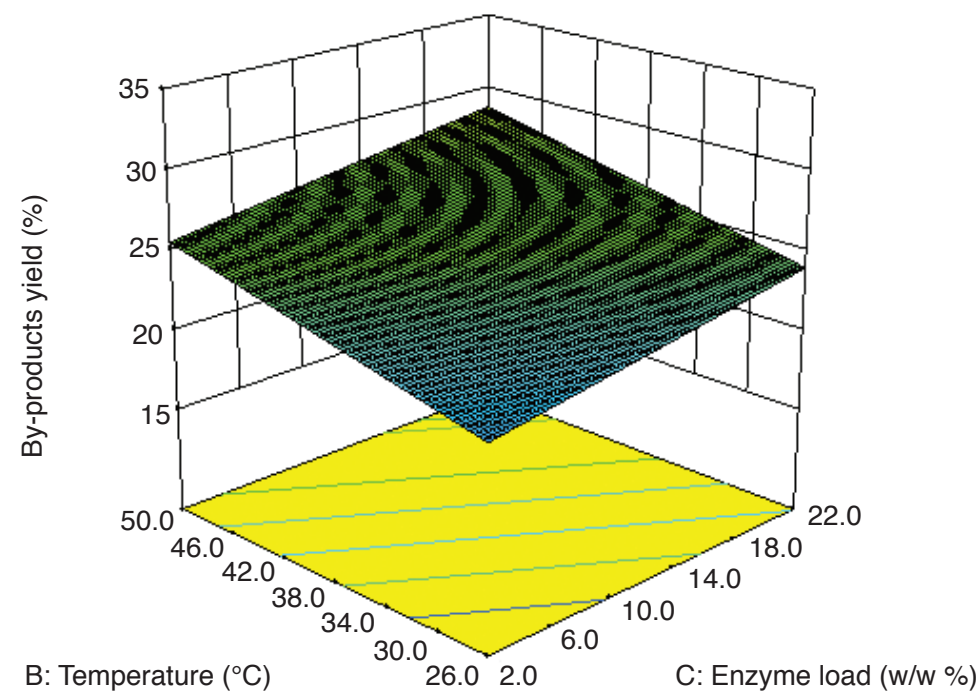

Figure 9. Contour and response surface plot of the effect of interaction between reaction temperature $\left({ }^{\circ} \mathrm{C}\right)$ and enzyme load $(w / w \%)$ at reaction time of $18 \mathrm{hr}$ on by-products (free fatty acids, monoacylglycerols and diacylglycerols) yield.

\section{Optimisation of EDIE of PO Reaction Conditions for the Highest Triunsaturated Triacylglycerol Yield}

The optimised EDIE reaction conditions were determined using the mathematical optimisation function in the Design Expert software to obtain the maximum yield of $\mathrm{U}_{3}$ TAG and to have the least possible amount of by-products. EDIE of PO reaction conditions which employed the lowest amount of lipase enzyme for the production of the highest amount of $\mathrm{U}_{3}$ TAG and the least possible amount of by-products within the shortest time was considered the most cost-efficient. Therefore, in determining the optimum reaction parameters, the enzyme load was fixed at $10 \%$ as the earlier ANOVA

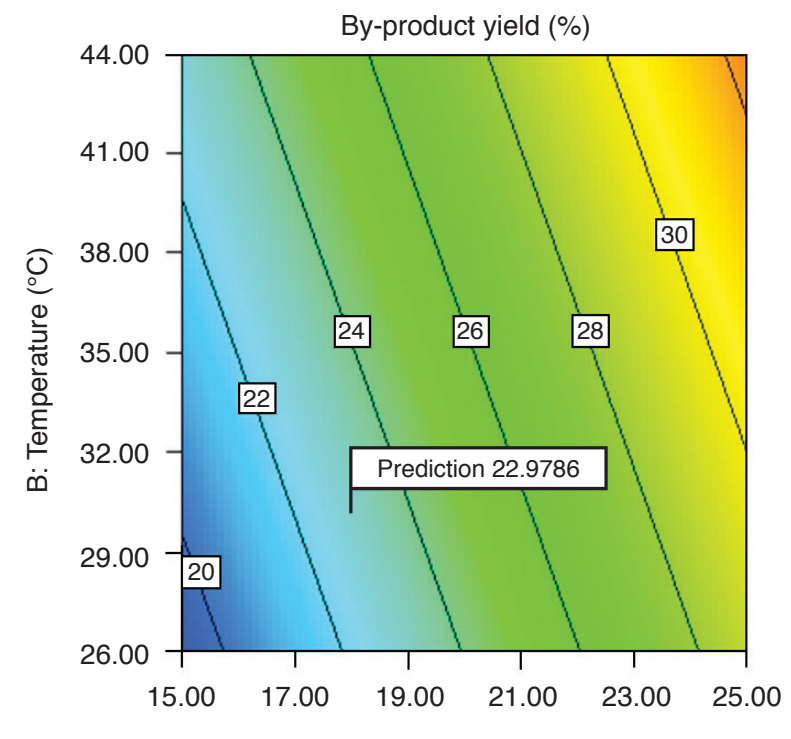

A: Time (hr) results had shown that an enzyme load of more than $10 \%$ had only a modest effect on $\mathrm{U}_{3}$ TAG yield. Based on the contour plots, a set of approximate reaction conditions which met the criteria of optimising $\mathrm{U}_{3}$ TAG yield and minimising the amount of byproducts formed were predicted.

The optimisation contour plot of the effects of reaction time and reaction temperature at $10 \%$ enzyme load on the $\mathrm{U}_{3}$ TAGs and by-product yields is shown in Figure 10. The most optimum reaction conditions when enzyme load was fixed at $10 \%$ were a reaction time of $18 \mathrm{hr}$ and a reaction temperature of $30.1^{\circ} \mathrm{C}$. These conditions were predicted to be able to produce EDIE PO containing $27 \% \mathrm{U}_{3} \mathrm{TAG}$ with about $23 \%$ of by-products. These optimised conditions gave a desirability value

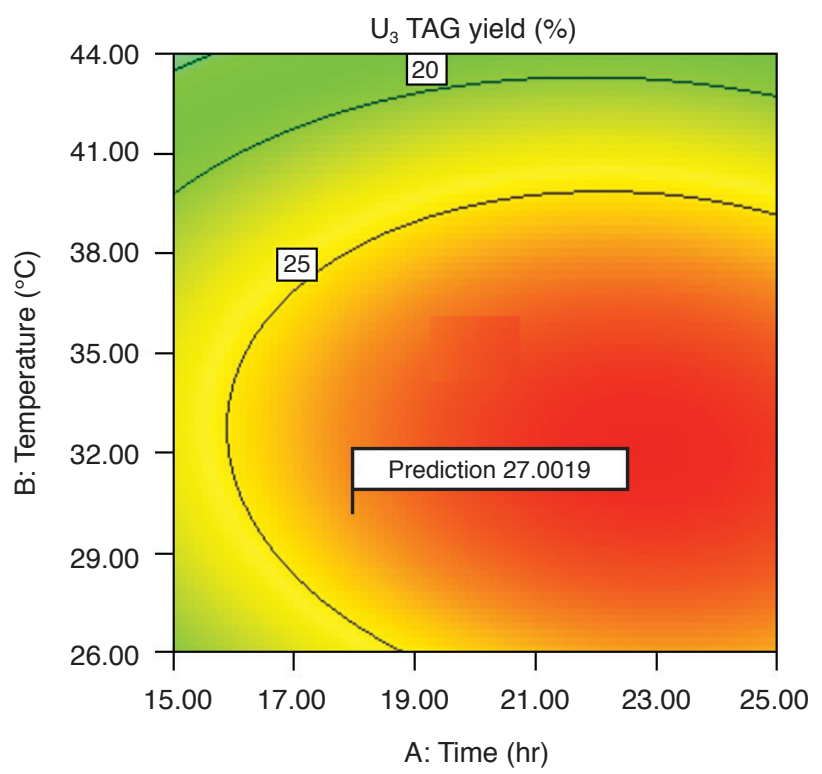

Figure 10. Contour plot of the effect of reaction time and reaction temperature at $10 \%$ enzyme load on the triunsaturated triacylglycerol $\left(U_{3} T A G\right)$ and by-product (free fatty acids, monoacylglycerols and diacylglycerols) yields. 
TABLE 5. TRIUNSATURATED TRIACYLGLYCEROL ( $\mathrm{U}_{3}$ TAG) AND BY-PRODUCTS (free fatty acids, monoacylglycerols and diacylglycerols) YIELDS FROM THREE VALIDATION RUNS USING THE OPTIMISED REACTION CONDITION AS COMPARED TO THE PREDICTED VALUE OF RESPONSE SURFACE METHODOLOGY OPTIMISATION

\begin{tabular}{ccc}
\hline Validation run & $\mathrm{U}_{3}$ TAG yield (\%) & By-products yield (\%) \\
\hline 1 & 26.67 & 21.01 \\
2 & 28.21 & 22.19 \\
3 & 28.88 & 24.36 \\
Predicted value & 27.00 & 22.97 \\
\hline
\end{tabular}

of 0.881 . Desirability is an objective function that reflects the desirable ranges for each factor and is defined as the geometric means of all transformed factors (Dalvand et al., 2014). Validation runs were carried out to validate the predicted results. Table 5 shows the yields of $\mathrm{U}_{3}$ TAG and by-products from three validation runs using the optimised reaction conditions compared with the predicted values of RSM optimisation. The yields of $\mathrm{U}_{3}$ TAG and byproducts obtained from the validation runs were very close to the predicted yields.

\section{CONCLUSION}

$\mathrm{U}_{3}$ TAG content in PO can be intensified via EDIE. RSM exploiting the CCD design with three factors and five levels $(-\alpha,-1,0,+1,+\alpha)$ was suitable for optimising the EDIE reaction conditions of $\mathrm{PO}$ for the production of $\mathrm{U}_{3}$ TAG. Well-fitted quadratic and linear models were successfully built for $\mathrm{U}_{3}$ TAG ( $\mathrm{R}^{2}$ of 0.9911$)$ and by-products $\left(\mathrm{R}^{2}\right.$ of 0.8733$)$ yields, respectively. $U_{3}$ TAG yield was affected significantly $(p<0.05)$ by all the three processing factors: reaction time, reaction temperature and enzyme load. The $\mathrm{U}_{3}$ TAG was strongly influenced by enzyme load, followed by reaction temperature and reaction time. By-products yield was affected significantly $(p<0.05)$ by reaction time and reaction temperature. Extending reaction time and increasing reaction temperature resulted in higher $\mathrm{U}_{3}$ TAG yield, but this was accompanied by higher by-products formation. The RSM optimised processing conditions for EDIE of $\mathrm{PO}$ to produce the utmost $\mathrm{U}_{3} \mathrm{TAG}$ and the least by-products were: a reaction temperature of $30.1^{\circ} \mathrm{C}$, a reaction time of $18 \mathrm{hr}$ and a Lipozyme TLIM lipase load of $10 \%(\mathrm{w} / \mathrm{w})$. It was predicted that these processing conditions would result in a $\mathrm{U}_{3}$ TAG yield of about $27 \%$ and by-products yield of about $23 \%$. Verification runs gave similar $\mathrm{U}_{3} \mathrm{TAG}$ and byproducts yields as predicted in the optimisation process.

\section{ACKNOWLEDGEMENT}

The authors acknowledge MPOB for the financial support to this research and permission to publish this article. The authors also acknowledge Isham Ismail and Muhamad Adrina Malek of Oils and Fats Technology Centre (OFTEC), MPOB for their contribution in ensuring the success of this study.

\section{REFERENCES}

ALVIZOURIMUÑOZ, M; CARRANZA MADRIGAL, J; HERRERA-ABARCA, J E; CHÁVEZ-CARBAJAL, $F$ and AMEZCUA GASTELUM, J L (1992). Effects of avocado as a source of monounsaturated fatty acids on plasma lipid levels. Archives of Medical Research, 23(4): 163-167.

BAŞ, D and BOYACI, I H (2007). Modeling and optimization I: Usability of response resurface methodology. J. Food Engineering, 78(3): 836-845.

BOOT, J; ROZENDAAL, A and SCHIJF, R (1984). Method for treating an edible oil by isothermal directed interesterification. US patent No. 4482576. Washington DC: US Patent and Trademark Office.

CAO, Y; QI, S; ZHANG, Y; WANG, X; YANG, B and WANG, Y (2013). Synthesis of structured lipids by lipase-catalyzed interesterification of triacetin with camellia oil methyl esters and preliminary evaluation of their plasma lipid-lowering effect in mice. Molecules, 18(4): 3733-3744.

CHOBANOV, D G and TOPALOVA, M R (1979). Alterations in glyceride composition during directed interesterification of lard. J. Amer. Oil Chem. Soc. Vol. 56(5): 581-584.

COWAN, D (2013). Enzyme processing. Edible Oil Processing (Hamm, W; Hamilton, R J and Calliauw, G eds.). United Kingdom: John Wiley \& Sons Ltd.

DALVAND, M J; MOHTASEBI, S S and RAFIEE, $S$ (2014). Optimization on drying conditions of a solar electrohydrodynamic drying system based on desirability concept. Food Science \& Nutrition, 2(6): 758-767.

DE LATHAUWER, $\mathrm{R} \mathrm{H}$; VAN OPSTAL, $\mathrm{M}$ and DIJKSTRA, A J (1981). Process for the directed interesterification of a triglyceride oil or oil mixture. 
US patent No. 4284578. Washington DC: US Patent and Trademark Office.

ELIBAL, B; SUZEN, H F; AKSOY, H A; USTUN, G and TUTER, M (2011). Production of structured lipids containing conjugated linolenic acid: Optimisation by response surface methodology. International $\mathrm{J}$. Food Science \& Technology, 46(7): 1422-1427.

FIRESTONE, D (2009). Official Methods and Recommended Practices of the AOCS. $6^{\text {th }}$ ed. Champaign, IL: American Oil Chemists' Society Press.

GALLAND, L (2010). Diet and inflammation. Nutrition in Clinical Practice, 25(6): 634-640.

GILLINGHAM, L G; HARRIS-JANZ, $\mathrm{S}$ and JONES, P J (2011). Dietary monounsaturated fatty acids are protective against metabolic syndrome and cardiovascular disease risk factors. Lipids, 46(3): 209-228.

GOING, L H (1967). Interesterification products and processes. J. Amer. Oil Chem. Soc. Vol. 44(9): A414-A456.

HAMAM, F and BUDGE, S (2010). Structured and specialty lipids in continuous packed column reactors: Comparison of production using one and two enzyme beds. J. Amer. Oil Chem. Soc. Vol. 87(4): 385-394.

HAWLEY, H K and HOLMAN, G W (1956). Directed interesterification as a new processing tool for lard. J. Amer. Oil Chem. Soc. Vol. 33(1): 29-35.

HU, F B and WILLETT, W C (2002). Optimal diets for prevention of coronary heart disease, JAMA, 288(20): 2569-2578.

HUANG, Y; ZHENG, H and YAN, Y (2010). Optimization of lipase-catalyzed transesterification of lard for biodiesel production using response surface methodology. Applied Biochemistry and Biotechnology, 160(2): 504-515.

HUYGHEBAERT, A; VERHAEGHE, D and DE MOOR, H (1994). Fat products using chemical and enzymatic interesterification. Fats in Food Products (Moran, D P J and Rajah, K K eds.). New York: Springer. p. 319-345.

KLEMANN, L P; AJI, K; CHRYSAM, M; D'AMELIA, R P; HENDERSON, J; HUANG, A; OTTERBURN, M S; YARGER, R G; BOLDT, G and RODEN, A (1994). Random nature of triacylglycerols by the catalyzed interesterification of short- and long-chain fatty acid triglycerides. J. Agricultural and Food Chemistry, 42(2): $442-446$
KUSHAIRI, A; SOH KHEANG LOH; AZMAN, I; ELINA HISHAMUDDIN; MEILINA ONGABDULLAH; ZAINAL BIDIN MOHD NOOR IZUDDIN; RAZMAH, G; SHAMALA SUNDRAM and GHULAM KADIR AHMAD PARVEEZ (2018). Oil palm economic performance in Malaysia and R\&D progress in 2017. J. Oil Palm Res. Vol. 30(2): 163-195.

LAGO, R C A and HARTMAN, L (1986). Directed interesterification of a brazilian palm oil and analysis of the original and interesterified oil and its fractions. J. Science of Food and Agriculture, 37(7): 689-693.

LEE, Y Y; TANG, T K; PHUAH, E T; NUR AZWANI, A K; SITI MASLINA, M A and LAI, O M (2015). Palm-based medium- and long-chain triacylglycerol (P-MLCT): Production via enzymatic interesterification and optimization using response surface methodology (RSM). J. Food Science and Technology, 52(2): 685-696.

MACKENZIE, A D and STEVENSON, D E (2000). Production of high-oleic acid tallow fractions using lipase-catalyzed directed interesterification, using both batch and continuous processing. Enzyme and Microbial Technology, 27(3): 302-311.

MARTINČIČ, V; GOLOB, J; DE GREYT, W; VERHÉ, R; KNEZ, S; VAN HOED, V; ŽILNIK, L F; POTOČNIK, K; HRAŠ, A R and AYALA, J V (2008). Optimization of industrial-scale deodorization of high-oleic sunflower oil via response surface methodology. European J. Lipid Science and Technology, 110(3): 245-253.

MU, H; XU, X and HØY, C (1998). Production of specific-structured triacylglycerols by lipasecatalyzed interesterification in a laboratory scale continuous reactor. J. Amer. Oil Chem. Soc. Vol. 75(9): 1187-1193.

NAQVI, A Z; HARTY, B; MUKAMAL, K J; STODDARD, A M; VITOLINS, M and DUNN, J E (2011). Monounsaturated, trans, and saturated fatty acids and cognitive decline in women. J. American Geriatrics Society, 59(5): 837-843.

NOOR LIDA, H M D; SUNDRAM, K; SIEW, W L; AMINAH, A and MAMOT, S (2002). TAG composition and solid fat content of palm oil, sunflower oil, and palm kernel olein blends before and after chemical interesterification. J. Amer. Oil Chem. Soc. Vol. 79(11): 1137-1144.

O'BRIEN, R D (2009). Fats and Oils: Formulating and Processing for Applications. Florida: CRC Press. 
ÖZTÜRK, T; USTUN, G and AKSOY, H A (2010). Production of medium-chain triacylglycerols from corn oil: Optimization by response surface methodology. Bioresource Technology, 101(19): 74567461.

PAULA, A V D; NUNES, G F M; CASTRO, H F D and SANTOS, J C D (2016). Assessing the reaction conditions to mediate the milkfat-soybean oil enzymatic interesterification. Brazilian J. Food Technology, 19: e2015116.

PLACEK, C and HOLMAN, G W (1957). Directed interesterification of lard. Industrial $\mathcal{E}$ Engineering Chemistry, 49(2): 162-169.

QIAN, F; KORAT, A A; MALIK, V and HU, F B (2016). Metabolic effects of monounsaturated fatty acid-enriched diets compared with carbohydrate or polyunsaturated fatty acid-enriched diets in patients with type 2 diabetes: A systematic review and meta-analysis of randomized controlled trials. Diabetes Care, 39(8): 1448-1457.

ROUSSEAU, D and MARANGONI, A G (2008). Chemical interesterification of food lipids: Theory and practice. Food Lipids Chemistry, Nutrition and Biotechnology (Akoh, C C and Min, D B eds.). Florida: CRC Press. p. 268-292.

ROZENDAAL, A (1990). Interesterification of oils and fats. World Conference Proceedings, Edible Fats and Oils Processing: Basic Principles and Modern Practices (Erickson, D R eds.). Champaign, IL: AOCS Press.

ROZENDAAL, A (1992). Interesterification of oils and fats. Inform, 3: 1232-1237.

RUDEL, L L; HAINES, J L and SAWYER, J K (1990). Effects on plasma lipoproteins of monounsaturated, saturated, and polyunsaturated fatty acids in the diet of African green monkeys. J. Lipid Research, 31(10): 1873-1882.

SARTORIUS, T; KETTERER, C; KULLMANN, S; BALZER, M; ROTERMUND, C; BINDER, S; HALLSCHMID, M; MACHANN, J; SCHICK, F; SOMOZA, V; PREISSL , H; FRITSCHE, A; HANS-HÄRING, U and HENNIGE, A M (2012). Monounsaturated fatty acids prevent the aversive effects of obesity on locomotion, brain activity, and sleep behavior. Diabetes, 61(7): 1669-1679.
SAW, M H and SIEW, W L (2014). The effectiveness of immobilized lipase Thermomyces lanuginosa in catalyzing interesterification of palm olein in batch reaction. J. Oleo Science, 63(3): 295-302.

SCHWINGSHACKL, L and HOFFMANN, G (2012). Monounsaturated fatty acids and risk of cardiovascular disease: Synopsis of the evidence available from systematic reviews and metaanalyses. Nutrients, 4(12): 1989-2007.

SCHWINGSHACKL, L; STRASSER, B and HOFFMANN, G (2011). Effects of monounsaturated fatty acids on glycaemic control in patients with abnormal glucose metabolism: A systematic review and meta-analysis. Annals of Nutrition and Metabolism, 58(4): 290-296.

SIEW, W L (2011). Palm oil. Vegetable Oils in Food Technology: Composition, Properties and Uses (Gunstone, F D eds.). New Jersey: John Wiley \& Sons. p. 59-93.

TARMIZI, A H A; SIEW, W L and AINIE, K (2008). Palm-based standard reference materials for iodine value and slip melting point. Analytical Chemistry Insights, 3: 127-133.

VERCAMBRE, M N; GRODSTEIN, F and KANG, J $H$ (2010). Dietary fat intake in relation to cognitive change in high-risk women with cardiovascular disease or vascular factors. European J. Clinical Nutrition, 64(10): 1134-1140.

XU, X; SKANDS, A R H; HØY, C E; MU, H; BALCHEN, S and ADLER-NISSEN, J (1998). Production of specific-structured lipids by enzymatic interesterification: Elucidation of acyl migration by response surface design. J. Amer. Oil Chem. Soc. Vol. 75(9): 1179-1186.

ZHANG, H (2007). Evaluation of practical process aspects for lipozyme TLIM catalyzed bulk fat modification in a batch reactor. The Open Biotechnology J., 1: 72-78.

ZHANG, H; XU, X; NILSSON, J; MU, H; ADLERNISSEN, J and HØY, C E (2001). Production of margarine fats by enzymatic interesterification with silica-granulated thermomyces lanuginose lipase in a large-scale study. J. Amer. Oil Chem. Soc. Vol. 78(1): 57-64. 